\title{
African Dust Storms Reaching Puerto Rican Coast Stimulate the Secretion of IL-6 and IL-8 and Cause Cytotoxicity to Human Bronchial Epithelial Cells (BEAS-2B)
}

\author{
Rosa I. Rodríguez-Cotto ${ }^{1,2}$, Mario G. Ortiz-Martínez ${ }^{1,2}$, Evasomary Rivera-Ramírez ${ }^{2,3}$, \\ Loyda B. Méndez ${ }^{2,4}$, Julio C. Dávila ${ }^{1,2}$, Braulio D. Jiménez-Vélez ${ }^{1,2^{*}}$ \\ ${ }^{1}$ Department of Biochemistry, University of Puerto Rico-Medical Sciences Campus, San Juan, Puerto Rico; \\ *Corresponding Author: braulio.jimenez@upr.edu \\ ${ }^{2}$ Center for Environmental and Toxicological Research, San Juan, Puerto Rico \\ ${ }^{3}$ Department of Biology, University of Puerto Rico-Río Piedras Campus, San Juan, Puerto Rico \\ ${ }^{4}$ Science and Technology School, Eastern University, Carolina, Puerto Rico
}

Received 26 July 2013; revised 27 August 2013; accepted 15 September 2013

Copyright (C) 2013 Rosa I. Rodríguez-Cotto et al. This is an open access article distributed under the Creative Commons Attribution License, which permits unrestricted use, distribution, and reproduction in any medium, provided the original work is properly cited.

\section{ABSTRACT}

African dust storm events (ADE) travel across the Atlantic Ocean (ADEAO) and reach the Puerto Rican coast (ADEPRC), potentially impacting air quality and human health. To what extent seasonal variations in atmospheric particulate matter (PM) size fractions, composition and sources trigger respiratory-adverse effects to Puerto Ricans is still unclear. In the present study, we investigated the pro-inflammatory and cytotoxic effects of PM samples harvested during ADEAO $\left(P_{10}\right)$, ADEPRC $\left(\mathrm{PM}_{2.5}\right.$ and $\left.\mathrm{PM}_{10}\right)$ and Non-ADE (Pre- and Post-ADEAO and Non-ADEPRC), using BEAS-2B cells. Endotoxins (ENX) in $\mathrm{PM}_{2.5}$ and $\mathrm{PM}_{10}$ extracts and traces of metals (TMET) in $\mathrm{PM}_{2.5}$ extracts were also examined. IL-6 and IL-8 secretion and cytotoxicity were used as endpoints. ADEAO and ADEPRC extracts were found to be more cytotoxic than Non-ADE and ADEAO were more toxic than ADEPRC extracts. $\mathrm{PM}_{10}$ extracts from ADEAO and Post-ADEAO caused significant secretion of IL-8. IL-6 and IL-8 secretion was higher following treatment with $\mathrm{PM}_{10}$ and $\mathrm{PM}_{2.5}$ ADEPRC than with Non-ADEPRC extracts. ENX levels were found to be higher in $\mathrm{PM}_{10}$ ADEAO than in the rest of the samples tested. TMET levels were higher in $\mathrm{PM}_{2.5}$ ADEPRC than in Non-ADEPRC extracts. Deferoxamine significantly reduced cytotoxicity and IL- 6 and IL-8 secretion whereas Polymyxin B did not. TMET in $\mathrm{PM}_{2.5}$ fractions is a major determinant in
ADEPRC-induced toxicity and work in conjunction with ENX to cause toxicity to lung cells in vitro. ENX and TMET may be responsible, in part, for triggering PM-respiratory adverse responses in susceptible and predisposed individuals.

Keywords: Dust Storm; Particulate Matter; Endotoxins; Metals; BEAS-2B Cells

\section{INTRODUCTION}

African dust storm events (ADE) have increased sharply since early 1970s. These environmental episodes have been attributed mainly to a drought period in the Saharan/Sahel region caused by changes in the global distribution of sea surface temperature [1-3]. Several hundred million tons of African dust is transported across the Atlantic Ocean (ADEAO) annually, leaving a trail of atmospheric pollutants throughout the Caribbean, Central and North America [4-7]. The seasonal influx of African dust, reaching the Northeastern coast of Puerto Rico (ADEPRC) during spring and summer, transports particulate matter (PM) capable of causing health-adverse effects [8-12]. However, to what degree ADEAO and ADEPRC fractions and constituents may contribute to the pathogenesis of respiratory and systemic illnesses observed in certain individuals during and after the ADEPRC, still remains unclear. More detailed (epidemiological, in vivo and in vitro) investigations are warranted to better understand the environmental factors and PM characteristics that play a critical role in the ADEPRC- 
induced respiratory related diseases.

Ambient PM is a complex mixture of solid and liquid particles of different sizes from various sources with distinct chemical compositions and constituents [13-18]. African dust carries large volumes of air masses characterized by a bimodal number distribution of particle sizes with a predominant mode near $0.6 \mu \mathrm{m}$ but shifts slightly towards larger modes when it reaches the western Atlantic/Caribbean sites $(1.2-2.5 \mu \mathrm{m}$ in diameter) $[19,20]$. Airborne PMs with a median aerodynamic diameter of equal or less than $2.5 \mu \mathrm{m}\left(\mathrm{PM}_{2.5}\right)$ and equal or less than $10 \mu \mathrm{m}\left(\mathrm{PM}_{10}\right)$ are known as fine and inhalable coarse fractions, respectively. Airborne $\mathrm{PM}_{2.5}$ arises from combustion processes or atmospheric transformation of combustion emissions whereas $\mathrm{PM}_{10}$ contains mainly mineral particles of crustal materials. $\mathrm{PM}_{2.5}$ and $\mathrm{PM}_{10}$ fractions have shown to contain organic materials (e.g., bacterial endotoxins (ENX), fungi (spores), pollen fragments, polycyclic aromatic hydrocarbons (PAH), and carbonaceous elements), as well as inorganic materials (e.g., water soluble traces of metals-TMET), minerals (quartz, silicates), salts (ammonium-sulfates and nitrates), and soil dust particles [3,14,18,21-24]. Ambient PMinduced health adverse effects can be triggered by the particle itself or the materials adsorbed to the particle [25-26]. When inhaled, this complex mixture may cause or exacerbate allergies, asthma, cardiovascular diseases and, in extreme cases, lung cancer and mortality [13-14, 19,24,27-36]. The extent of detrimental response to ambient PM exposure depends on different factors such as environmental (e.g., PM size and chemical constituents, demographics sources, climate and temperature changes, ozone and anthropogenic influences) and inter-individual variations (e.g., age, ethnicity, sex, health conditions and genetic predisposition). These multifactorial characteristics make difficult to underline the exact mechanism of PM-induced respiratory adverse effects. However, several in vitro studies have suggested different cell mechanisms associated to certain PM constituents such as: 1) bacterial ENX may be responsible for the inflammatory response due to the activation of Toll-like receptor-4 (TLR4) and transcription factors (e.g., NF-kB) and the release of pro-inflammatory cytokines (e.g., IL-6 and IL-8); 2) TMET [e.g., aluminum (Al), arsenic (As), iron $(\mathrm{Fe})$, cadmium $(\mathrm{Cd})$, copper $(\mathrm{Cu})$, nickel $(\mathrm{Ni})$, mercury $(\mathrm{Hg})$, lead $(\mathrm{Pb})$ and vanadium $(\mathrm{V})]$ may cause cellular lipids, proteins and DNA damage, mutagenicity and carcinogenicity by generating reactive oxygen species (ROS); 3) PAH may cause oxidative stress, aberrant changes in cell cycling, gene expression and DNA functions by generating toxic metabolites due to the activation of aryl hydrocarbon $(\mathrm{Ah})$ receptors and induction of Phase I and II metabolizing enzymes; and 4) air pollutants such as nitro-, sulfur- and oxygen-elements (e.g.,
$\mathrm{NO}_{2}, \mathrm{SO}_{2}, \mathrm{H}_{2} \mathrm{~S}, \mathrm{O}_{3}$ ) may cause lung epithelial cell damage, oxidative cellular stress and carcinogenicity [3, 25-26,29,34,37-47]. Based on these and other published studies (Aust et al., 2002; Wang et al., 2013), inflammatory injury and oxidative damage are considered as common mechanisms of PM-induced health adverse effects.

Respiratory illnesses, such as allergy and asthma, in the Caribbean region have increased over the past 30 years, where the pediatric population has been particularly the most affected [12,48-51]. The association between respiratory illnesses in children and the presence of atmospheric contaminants as well as the mechanisms by which these adverse effects occur are not well understood. However, there is a growing body of evidence indicating that African dust storms transporting $\mathrm{PM}_{2.5}$ and $\mathrm{PM}_{10}$ fractions and contaminants, such as ENX and TMET, may play a major role in the pathogenesis of respiratory illness and contribute to the increase of emergency room (ER) visits and hospitalizations of children [48,52-54].

In the present study we investigated the pro-inflammatory and cytotoxic effects of ambient PM $\left(\mathrm{PM}_{2.5}\right.$ and $\mathrm{PM}_{10}$ ) and its specific constituents (ENX and TMET) before, during and after dust storms (ADEAO and ADEPRC) using an in vitro model of BEAS-2B cells. The goal was to evaluate the hypothesis that ADE influx impacts the Puerto Rican coast air quality conditions and may be responsible, in part, for the respiratory-illnesses observed in susceptible and predisposed individuals.

\section{MATERIALS AND METHODS}

\subsection{Sampling Selection}

\subsection{1. $\mathrm{PM}_{10}$ Collected Over the Atlantic Ocean (AO)}

The ADEAO $\mathrm{PM}_{10}$ samples used in this study were collected in 2004 during the Aerosol and Oceanographic Science Expedition (AEROSE). Details of the AEROSE science plan, mission and sampling collection have already been reported elsewhere [10,20]. Briefly, the AEROSE project consisted of a series of intensive field experiments conducted aboard the U.S. National Oceanic and Atmospheric Administration (NOAA) ship Ronald $\mathrm{H}$. Brown during the North Hemispheric spring (March 2004) and summer (June-July 2007) expedition. $\mathrm{PM}_{10}$ samples were collected during the AEROSE-I, which started on February 29, 2004 in Bridgetown, Barbados and ended in San Juan, Puerto Rico on March 27. March $\mathrm{PM}_{10}$ samples were selected for this investigation to correlate them with samples gathered during a severe dust storm event that reached the coast of Puerto Rico during this time period. In addition, airborne dust samples present before (Pre-ADEAO) and after (Post-ADEAO) 
ADEAO were also collected during the AEROSE-I expedition and analyzed for comparison purposes.

\subsection{2. $\mathrm{PM}_{2.5}$ and $\mathrm{PM}_{10}$ Collected at Fajardo, Puerto Rican Coast (ADEPRC)}

A total of 28 ADEPRC were monitored during 2004. The identification of 5 of these ADEPRC in March allowed the harvest and preparation of a composite sample mixture containing sufficient material to obtain extract for this research. During spring and summer of the year studied, the PM mass concentration data showed a Puerto Rico seasonal variation pattern with high levels of $\mathrm{PM}_{2.5}$ and $\mathrm{PM}_{10}$ fractions, which correlated with the temporal dust events pattern detected by the Total Ozone Mapping Spectrometer (TOMS). $\mathrm{PM}_{2.5}$ samples were collected on Teflon filters while $\mathrm{PM}_{10}$ samples on quartz filters by the PR Environmental Quality Board (PR-EQB) air monitoring program. The air samplers were identified as EQB station 22, located at the northeastern coast of PR, close to a lighthouse in the municipality of Fajardo. This station is situated at a remote site (natural reserve) that minimizes possible anthropogenic PM contributions. In order to designate the days containing the $\mathrm{PM}_{2.5}$ and $\mathrm{PM}_{10}$ events originating from the African continent, a combination of two data sources was used. One source was the daily satellite images gathered by TOMS [6] and the other was the onsite $\mathrm{PM}_{2.5}$ and $\mathrm{PM}_{10}$ concentrations obtained by the PR-EQB (Figure 1). A relative increase above the lowest $\mathrm{PM}_{2.5}$ and $\mathrm{PM}_{10}$ daily mean concentrations $\left(2.8 \mu \mathrm{g} / \mathrm{m}^{3}\right.$ and $18.3 \mu \mathrm{g} / \mathrm{m}^{3}$, respectively) at Fajardo location was established as criteria to suggest the possible occurrence of a dust event. Once it was identified by means of weight, the dates were evaluated further by the confirmation of clouds over the region using images from TOMS. The ADEPRC sample set included PM collected a day before and $1-2$ days after the event since smaller particles from the event still remain in suspension after the main cloud front. The Non-ADE days were classified from the same period as the ADEAO. Samples harvested during the months of January, February, October, November and December of 2004, fulfilled the criteria of Non-ADE according to the guidelines mentioned above and were used as classification controls.

\section{2. $\mathrm{PM}_{2.5}$ and $\mathrm{PM}_{10}$ Extractions}

All glassware used was acid washed using a modified cleanup procedure as described by Molinelli et al., 2006 [22]. Briefly, all filters were extracted for a $48 \mathrm{~h}$ period in $150-200 \mathrm{ml}$ of hexane/acetone (Fisher, H303SK4 and A9294) 1:1 using a Soxhlet extraction apparatus. The resulting extracts were reduced to a volume of $2-8 \mathrm{ml}$ using a rotor evaporator under vacuum, subsequently dried under a gentle stream of pure nitrogen and their

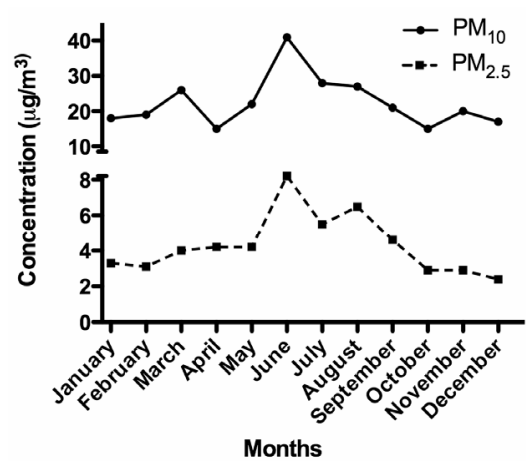

Figure 1. $\mathrm{PM}_{2.5}$ and $\mathrm{PM}_{10}$ monthly mean concentrations reported in 2004 by PR-EQB for the rural coastal region of Fajardo, Puerto Rico.

masses determined gravimetrically. The organic extracts were dissolved in dimethylsulfoxide (DMSO, Sigma, Cat No D2650) to a concentration of $100 \mathrm{mg} / \mathrm{ml}$. All extracts were stored at $-20^{\circ} \mathrm{C}$ until further use. Blank filters were also extracted using the previous methodology for quality control purposes.

\section{3. $P M_{2.5}$ and $P M_{10}$ Endotoxin Quantification}

\subsubsection{Filters}

ENX in $\mathrm{PM}_{10}$ filters collected at sea during AEROSE were determined with the Kinetic Limulus Amebocyte Lysate assay (Pyrochrome, Associates of Cape Cod, East Falmouth, MA, USA) following the manufacturer's instructions.

\subsubsection{Extracts}

ENX concentrations in $\mathrm{PM}_{10}$ and $\mathrm{PM}_{2.5}$ organic extracts were determined in duplicate using the Kinetic Limulus Amebocyte Lysate Assay (Kinetic-QCL, Lonza, Walkersville, MD, USA) as described by the manufacturer. A $1 / 1000$ organic extract dilution was used to quantify ENX in the extracts. A Lipopolysaccharide (LPS, Sigma, Cat No L2630) positive control was included for each sample in order to guarantee the specificity of the assay. Absorbance readings at $37^{\circ} \mathrm{C}$ were recorded on an $\mathrm{EL}_{\mathrm{x}} 808$ micro-plate reader (Biotek Instruments Inc., Winooski, VT, USA) and data analysis was performed with the WinKQCL Software (Lonza, Walkersville, MD, USA).

\section{4. $\mathrm{PM}_{2.5}$ Metal Analyses}

$\mathrm{PM}_{2.5}$ organic extracts were diluted in $1 \mathrm{ml}$ of $2 \%$ nitric acid and metals quantified by inductive coupled plasma mass spectrometry using an Agilent 7500 (ICPMS). A modified Environmental Protection Agency 200.8 method was employed. The modification consisted of using helium or hydrogen to remove isobaric interferences through a reaction cell. Each sample was run in 
triplicate and mean concentration determined for: aluminum $(\mathrm{Al})$, cadmium $(\mathrm{Cd})$, copper $(\mathrm{Cu})$, iron $(\mathrm{Fe})$, lead $(\mathrm{Pb})$ and vanadium $(\mathrm{V})$.

\subsection{Cell Culture and Treatments}

BEAS-2B cells were obtained from the American Type Culture Collection (ATCC, Manassas, VA, USA; Cat No CRL-9609). Cells were cultured according to ATCC protocols, maintained in keratinocyte basal medium (KBM-2, Lonza, Walkersville, MD, USA Cat No CC 3103) and supplemented with keratinocyte growth medium (KGM-2 SingleQuots; Lonza, Walkersville, MD, USA; Cat No CC4152). Cells were used at passages 44 59 and maintained at $37^{\circ} \mathrm{C}$ in a humidified atmosphere of $5 \% \mathrm{CO}_{2}$. Cells were seeded at a density of $5 \times 10^{4}$ cells/well onto 96-well plates and incubated for $24 \mathrm{~h}$. Extracts were diluted in cell media at final concentration of $0.1 \%$ DMSO and used to expose cells to $\mathrm{PM}_{10}$ (ADEAO and ADEPRC) and $\mathrm{PM}_{2.5}$ (ADEPRC) at concentrations ranging from 10 to $100 \mu \mathrm{g} / \mathrm{ml}$ for $24 \mathrm{~h}$. Based on diesel exhaust particles studies [55], this extract concentration range is biologically relevant. Using this range it is possible to induce biologic effects and can be achieved in vivo after the appropriate adjustments (e.g. breathing patterns, airway anatomy, diseased airways, particle size and deposition). Three independent exposure experiments were performed. Two additional set of cells ( $n=3$ independent dishes) were also used to concurrently be treated for a $24 \mathrm{~h}$ period with: 1) ADEPRC $\mathrm{PM}_{10}$ organic extract (10 and $25 \mu \mathrm{g} / \mathrm{ml}$ ) pre-incubated with polymyxin B sulfate (PMB, Sigma Cat No P0972), an ENX inhibitor, at a final concentration $10 \mu \mathrm{g} / \mathrm{ml}$; and 2) $\mathrm{ADEPRC} \mathrm{PM}_{2.5}$ organic extract $(50,75$ and $100 \mu \mathrm{g} / \mathrm{ml})$ pre-incubated with deferoxamine mesylate (DF, Sigma, Cat No D9533), a metal chelator, at a final concentration of $50 \mu \mathrm{M}$. Appropriate positive (LPS at a final concentration of $10 \mathrm{ug} / \mathrm{ml}$ and LPS pre-treated with PMB) and negative controls (medium, DMSO and media with DF and PMB) were run simultaneously in each experiment. Cell supernatants were collected after each exposure and stored at $-80^{\circ} \mathrm{C}$ until further cytokine analyses.

\subsection{Cell Viability}

The Neutral Red bioassay was employed to assess cell viability. Following $24 \mathrm{~h}$ treatment with PM extracts and inhibitors, BEAS-2B cells were incubated with Neutral Red dye (Sigma, Cat No N2889) at a final concentration of $100 \mu \mathrm{g} / \mathrm{ml}$ for $3 \mathrm{~h}$. The dye was then removed; cells were fixed in $1 \%$ calcium chloride, $0.5 \%$ formaldehyde, rinsed with phosphate buffered saline (PBS) and lysed using $1 \%$ acetic acid and $50 \%$ ethanol. Cell viability was spectrophotometrically determined at $540 \mathrm{~nm}$ using an Ultramark microplate reader (Bio Rad, Richmond, CA,
USA). Three independent cytotoxicity experiments were performed. Triton-X $(50 \mu \mathrm{g} / \mathrm{ml})$ was used as a positive control for cell toxicity. Negative controls exhibited $90 \%$ or greater cell viability. A viability of less than $80 \%$ was considered cytotoxic, leaving a range of $20 \%$ for normal cell death.

\subsection{Cytokine Secretion Measurements}

The levels of IL-6 and IL-8, as well as other pro-inflammatory cytokines and proteins such as TNF- $\alpha$, interleukin-1 beta (IL-1 $\beta$ ), monocyte chemotactic protein-1 (MCP-1) and granulocyte-macrophage colony-stimulating factor (GM-CSF) were analyzed using a multiplex bead assay (MAP Kit from Millipore, Billerica, MA, USA or Fluorokine Multi-analyte Profiling Kit from R \& D Systems, Minneapolis, MN, USA) according to the manufacturer's instructions. Cytokine concentrations were determined using the dual laser flow analyzer Luminex 100 (Luminex Corp, Austin, TX, USA). Standard curves for each cytokine were plotted employing a 5-paremeter logistic fit (5-PL). Three independent cytokine secretion experiments were performed.

\subsection{Statistical Analyses}

To assess differences among groups ANOVA statistical assays were performed followed by the non-parametric Tukey test for multiple comparisons. To analyze differences between individual groups the unpaired Student's $t$ Test was employed. The criterion for statistical significance was set at $\mathrm{p} \leq 0.05$. Statistical analyses were performed using the GraphPad InStat 3 software. Analyses were based on 3 independent experiments per cell response.

\section{RESULTS}

\section{1. $\mathrm{PM}_{10}$ Fractions}

\subsubsection{ENX Levels and Cytotoxicity of $P M_{10}$ ADEAO and ADEPRC Extracts}

ADEAO extracts were found to be more cytotoxic to BEAS-2B cells than extracts from Pre-ADEAO, but as toxic as Post-ADEAO (Figure 2(a)). Pre-ADEAO samples were not toxic to BEAS-2B cells at all. ADEAO samples were found to be as toxic as ADEPRC samples $\left(\mathrm{LC}_{50}=37 \mu \mathrm{g} / \mathrm{ml}\right.$ and $38 \mu \mathrm{g} / \mathrm{ml}$, respectively). ADEPRC extracts showed a dose-response cytotoxic effect and were highly toxic at $25 \mu \mathrm{g} / \mathrm{ml}$ (Figure 2(b)). The ADEPRC and Non-ADEPRC extracts tested showed a non-significant increase in cell viability with the addition of PMB (Figure 3) at either dose of 10 or $25 \mu \mathrm{g} / \mathrm{ml}$.

$\mathrm{PM}_{10}$ ADEAO extracts contained approximately 5 times the amount of ENX found in the Pre-ADEAO or Post-ADEAO extracts (Table 1). ENX levels present in 


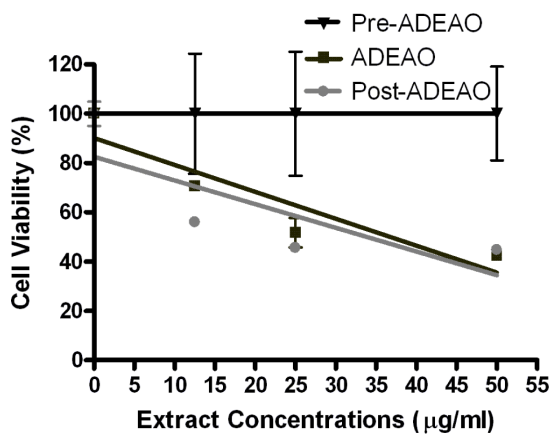

(a)

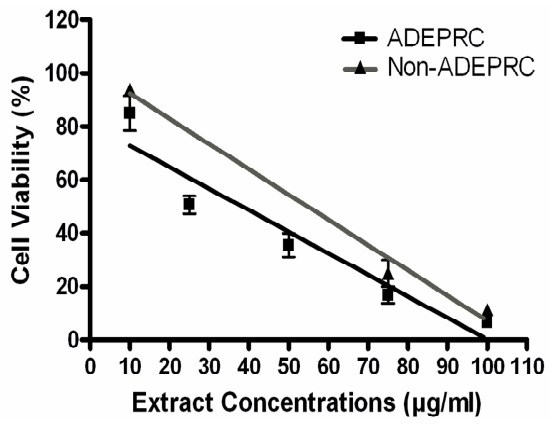

(b)

Figure 2. Cytotoxic effect of $\mathrm{PM}_{10}$ extracts in BEAS-2B Cells. Cells were treated for $24 \mathrm{~h}$ with $\mathrm{PM}_{10}$ extracts collected from the Atlantic Ocean (A: ADEAO) and Puerto Rican Coast (B: ADEPRC). LC $_{50}$ (lethal concentration of the PM extracts that kills $50 \%$ of the cells in $24 \mathrm{~h}$ ) values were determined. ADEAO $\left(\mathrm{LC}_{50}=37 \mu \mathrm{g} / \mathrm{ml}\right.$; Post-ADEAO $\left.\mathrm{LC}_{50}=34 \mu \mathrm{g} / \mathrm{ml}\right)$ and ADEPRC $\left(\mathrm{LC}_{50}=38 \mu \mathrm{g} / \mathrm{ml}\right.$; Non-ADEPRC $\left.\mathrm{LC}_{50}=55 \mu \mathrm{g} / \mathrm{ml}\right)$ extracts were cytotoxic; however pre-ADEAO extracts were not. All extract concentrations were tested in 3 independent experiments.

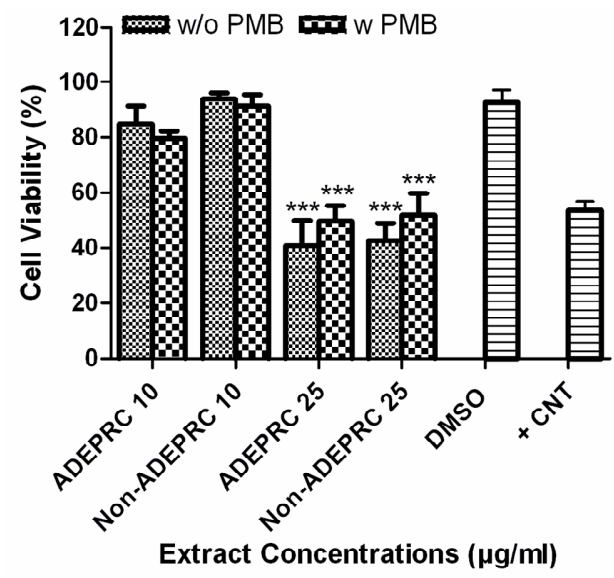

Figure 3. Effect of Polymyxin B (PMB, an ENX inhibitor) and $\mathrm{PM}_{10}$ ADEPRC extracts on BEAS-2B cell viability. Cells were treated with $\mathrm{PM}_{10}$ ADEPRC extracts in the presence (w PMB) and absence of PMB (w/o PMB) at $10 \mu \mathrm{g} / \mathrm{ml}$ for $24 \mathrm{~h}$ and cell viability was evaluated. Triton-X $(+\mathrm{CNT})$ at $25 \mu \mathrm{g} / \mathrm{ml}$ was used as positive control. Bars represent mean cell viability \pm SEM. Stars over the bars indicate comparison of a treatment with DMSO. All samples were tested in three independent experiments; ${ }^{* * *} \mathrm{p}<0.001$ the $\mathrm{PM}_{10}$ oceanic quartz filters were found to be as high as $6.41 \mathrm{EU} / \mathrm{m}^{3}$ during $\mathrm{ADEAO}$ as compared to 0.50 in Pre-ADEAO and $0.80 \mathrm{EU} / \mathrm{m}^{3}$ in Post-ADEAO. $\mathrm{PM}_{10}$ ADEAO ENX levels were higher when compared to those found in $\mathrm{PM}_{10}$ ADEPRC extracts, 511 and 114 $\mathrm{EU} / \mathrm{mg}$, respectively. The amount of ENX present in $\mathrm{PM}_{10}$ organic extracts was also higher than that found in $\mathrm{PM}_{2.5}$ samples, <50 EU/mg (Table 1).

\subsubsection{IL-6 and IL-8 Release by $\mathrm{PM}_{10}$ ADEAO and ADEPRC Extracts}

ADEAO and Post-ADEAO extracts at $25 \mu \mathrm{g} / \mathrm{ml}$ induced significantly IL-8 secretion (Figure 4) while PreADEAO extracts did not. The IL-6 and IL- 8 secretion was significantly higher in ADEPRC extracts than in Non-ADEPRC (Figures 5(a) and (b)). The use of PMB on ADEPRC and Non-ADEPRC extracts decreased the levels of IL-6, but not significantly. Conversely, PMB was found to increase significantly the secretion of IL-8 in the presence of the ADEPRC extracts at $10 \mu \mathrm{g} / \mathrm{ml}$ (Figure 5(b)). PMB and DMSO alone did not cause any

Table 1. Endotoxin concentration in $\mathrm{PM}_{2.5}$ and $\mathrm{PM}_{10}$ extracts.

\begin{tabular}{ccc}
\hline Particulate Matter & Sample & Endotoxins $\left(\mathrm{EU}^{\mathrm{a}} / \mathrm{mg}\right)$ \\
\hline $\mathrm{PM}_{10}$ & Pre-ADEAO & 155.0 \\
& ADEAO & 511.0 \\
& Post-ADEAO & 75.9 \\
& ADEPRC & 114 \\
& Non-ADEPRC & 111 \\
& ADEPRC & $<50$ \\
$\mathrm{PM}_{2.5}$ & Non-ADEPRC & $<50$ \\
\hline
\end{tabular}

${ }^{a}$ Endotoxin Units

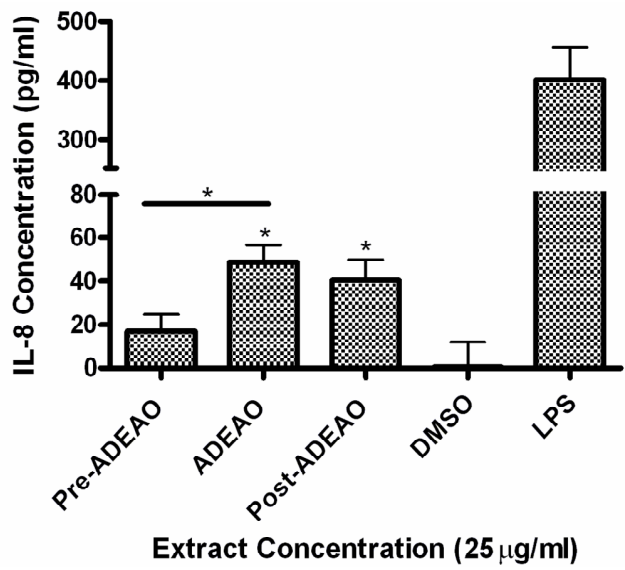

Figure 4. Induction of IL- 8 in BEAS-2B exposed to $\mathrm{PM}_{10}$ extracts collected before, during and after the Atlantic Ocean dust storm (ADEAO). LPS $(10 \mu \mathrm{g} / \mathrm{ml})$ was used as a positive control. Bars represent mean IL-8 concentrations \pm SEM. Stars over the bars indicate comparison of a treatment with DMSO. Stars over the line indicate a comparison between two treatments. All samples were tested in three independent experiments; ${ }^{*} \mathrm{p}<0.05$. 


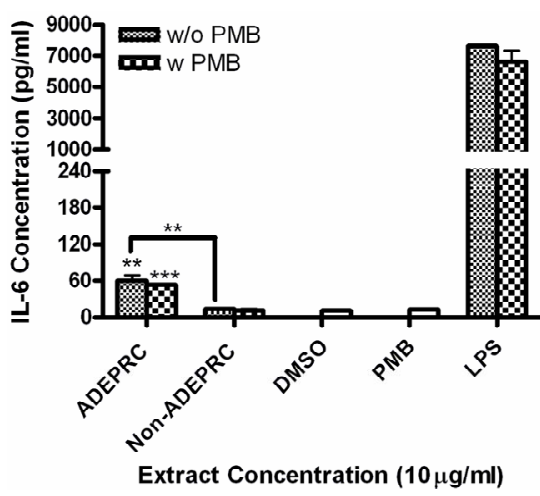

(a)

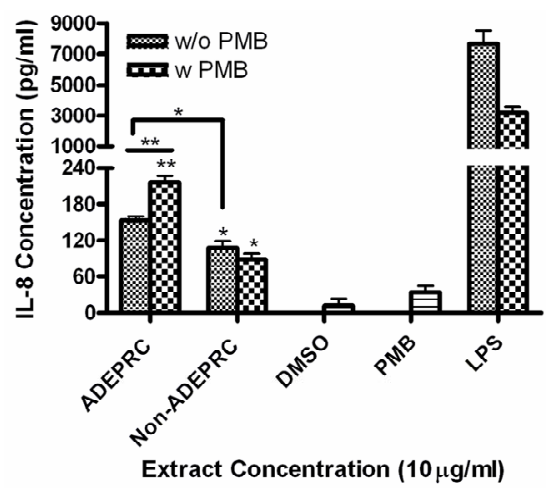

(b)

Figure 5. Effect of Polymyxin $\mathrm{B}$ (PMB, an ENX inhibitor) at $10 \mu \mathrm{g} / \mathrm{ml}$ on the induction IL-6 (A) and IL-8 (B) in BEAS-2B exposed to $\mathrm{PM}_{10}$ (ADEPRC) extracts for $24 \mathrm{~h}$. Cells were treated with $\mathrm{PM}_{10}$ ADEPRC extracts in the presence (w PMB) and absence of PMB (w/o PMB) and cytokine induction was measured. LPS $(10 \mu \mathrm{g} / \mathrm{ml})$ was used as a positive control. Bars represent mean IL-8 concentration \pm SEM. Stars over the bars indicate comparison of a treatment with DMSO. Stars over the line indicate a comparison between two treatments. All samples were tested in three independent experiments; ${ }^{* * *} \mathrm{p}<0.001,{ }^{* *} \mathrm{p}$ $<0.01,{ }^{*} \mathrm{p}<0.05$.

changes in IL-6 or IL-8 levels. Furthermore, extracts did not provoke secretion of any of the other pro-inflammatory mediators tested such as TNF- $\alpha$, IL- $1 \beta$, GM-CSF and MCP-1 (data not shown).

\section{2. $\mathrm{PM}_{2.5}$ Fractions}

\subsubsection{Cytotoxicity of $\mathrm{PM}_{2.5}$ ADEPRC Extracts}

The dose-response exhibited an inverse relationship between cell viability and extract concentration (ADEPRC $\mathrm{R}^{2}=0.96$ and Non-ADEPRC $\mathrm{R}^{2}=0.81$ ). ADEPRC extracts were more toxic than Non-ADEPRC to BEAS-2B cells (Figure 6). ADEPRC extracts were concurrently tested with DF at various concentrations. DF increased cell viability at all concentrations tested and a significant effect was observed at $75 \mu \mathrm{g} / \mathrm{ml}$ (Figure 7(a)). Non-ADEPRC (Figure 7(b)) incubated with DF did not significantly increase cell viability at 75 and

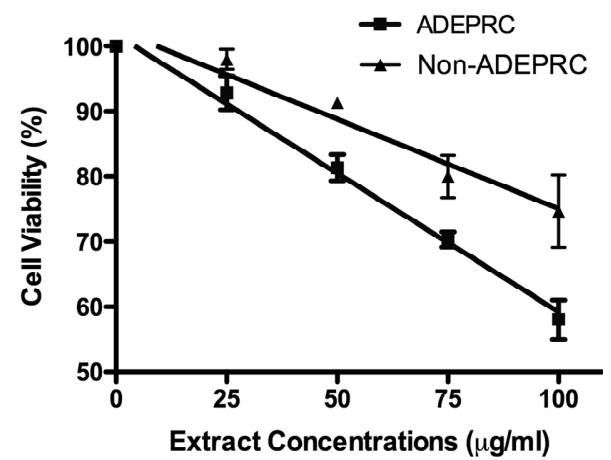

Figure 6. Cytotoxic effect of $\mathrm{PM}_{2.5}$ extracts in BEAS-2B Cells. Cells were treated for $24 \mathrm{~h}$ with $\mathrm{PM}_{2.5}$ extracts collected in the Puerto Rican coast during the African storm (ADEPRC) and non-storm (Non-ADEPRC) season. $\mathrm{LC}_{50}$ (lethal concentration of the PM extracts that kills $50 \%$ of the cells in $24 \mathrm{~h}$ ) values were determined. ADEPRC $\left(\mathrm{LC}_{50}=122 \mu \mathrm{g} / \mathrm{ml}\right.$ (extrapolated) and Non-ADEPRC $\left(\mathrm{LC}_{50}=191 \mu \mathrm{g} / \mathrm{ml}\right.$ (extrapolated) were cytotoxic. All extract concentrations were tested in 3 independent experiments.

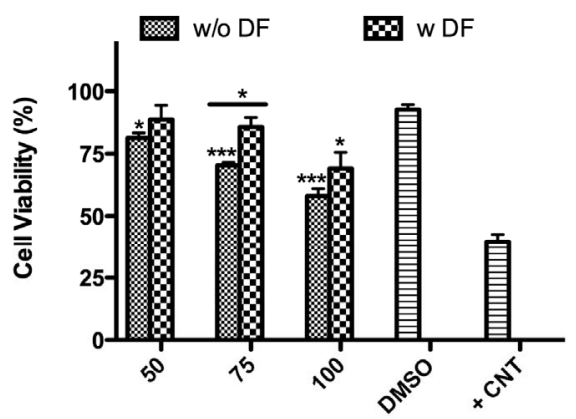

ADEPRC Extract Concentrations $(\mu \mathrm{g} / \mathrm{ml})$

(a)

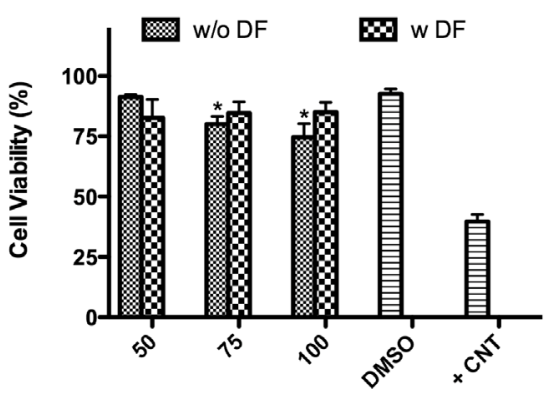

Non- ADEPRC Extract Concentrations $(\mu \mathrm{g} / \mathrm{ml})$

(b)

Figure 7. Effect of Deferoxamine (DF, a metal chelator) and $\mathrm{PM}_{2.5}$ ADEPRC extracts on BEAS-2B cell viability. Cells were treated with $\mathrm{PM}_{25}$ extracts collected during the dust storm (ADEPRC) and non-storm (Non-ADEPRC) season in the presence (w DF) and absence of DF (w/o DF) at $50 \mu \mathrm{M}$ for 24 $\mathrm{h}$ and cell viability was evaluated. Triton-X $(+\mathrm{CNT})$ at 25 $\mu \mathrm{g} / \mathrm{ml}$ was used as positive control. Bars represent mean cell viability \pm SEM. Stars over the bars indicate comparison of a treatment with DMSO. Stars over the line indicate a comparison between two treatments. All extract concentrations were tested in 3 independent experiments; ${ }^{* * *} \mathrm{p}<0.001,{ }^{*} \mathrm{p}<0.05$. 
$100 \mu \mathrm{g} / \mathrm{ml}$. Cytotoxicity caused by ADEPRC extracts correlated with the presence of high levels of metals, including $\mathrm{Cu}, \mathrm{Pb}$ and $\mathrm{V}$ (Table 2).

\subsubsection{IL-6 and IL-8 release by $\mathrm{PM}_{2.5}$ ADEPRC Extracts}

Significant differences were observed on immunological responses between ADEPRC and Non-ADEPRC particularly on the induction of IL-6 and IL-8 secretion by BEAS-2B (Figures 8(a) and (b)). This effect follows that of a dose-response type. This induction was distinct at the non-toxic concentrations of PM extracts tested at 25 and $50 \mu \mathrm{g} / \mathrm{ml}$. It is evident that the effect of ADEPRC extracts on cytokine secretion by BEAS-2B was far more prominent than in the Non-ADEPRC extracts. Cells simultaneously treated with ADEPRC extracts at $50 \mu \mathrm{g} / \mathrm{ml}$ and DF at $50 \mu \mathrm{M}$ reduced IL-6 (Figure 9(a)) and significantly IL-8 (Figure 9(b)) secretions. This effect was also observed with the Non-ADEPRC extracts, but not significantly. $\mathrm{PM}_{2.5}$ extracts significantly decreased the secretion of MCP-1. No changes were observed with the use of DF (data not shown). $\mathrm{PM}_{2.5}$ extracts did not cause any change in other pro-inflammatory mediators such as TNF- $\alpha$, IL- $1 \beta$ and GM-CSF (data not shown).

\subsubsection{TMET Levels in $\mathrm{PM}_{2.5}$ ADEPRC Samples}

$\mathrm{Al}, \mathrm{Cd}, \mathrm{Cu}, \mathrm{Fe}, \mathrm{Pb}$, and $\mathrm{V}$ were measured to determine their contribution to the toxicity and pro-inflammatory characteristics on ADEPRC extracts (Table 2). The ADEPRC extracts contained relative amounts of TMET and were ranked as follows: $\mathrm{Cd}<\mathrm{V}<\mathrm{Pb}<\mathrm{Al}<\mathrm{Cu}<\mathrm{Fe}$. The Non-ADEPRC extracts were also ranked as follows: $\mathrm{Cd}<\mathrm{V}<\mathrm{Pb}<\mathrm{Cu}<\mathrm{Al}<\mathrm{Fe}$. The most abundant TMET in ADEPRC extracts were $\mathrm{Cu}, \mathrm{Pb}$ and $\mathrm{V}$ and were higher than Non-ADEPRC. The total metal distribution in ADEPRC and Non-ADEPRC extracts (Table 2), which include both the organic and aqueous phase, shows the

Table 2. Metal Content in Organic Extracts vs Total Composition.

\begin{tabular}{ccccc}
\hline \multirow{4}{*}{$\begin{array}{c}\text { Trace } \\
\text { Element }\end{array}$} & \multicolumn{3}{c}{ Organic Extracts } & \multicolumn{2}{c}{ Total } \\
\cline { 2 - 5 } & ADEPRC Non-ADEPRC & ADEPRC & Non-ADEPRC \\
\hline $\mathrm{Al}$ & $\mathbf{1 6 . 4}$ & $\mathbf{3 3 . 3}$ & 63.5 & 54.7 \\
$\mathrm{Fe}$ & $\mathbf{3 9 . 9}$ & $\mathbf{4 0 . 4}$ & 16.8 & 13.3 \\
$\mathrm{Cd}$ & $\mathbf{0 . 4}$ & $\mathbf{0 . 3}$ & 0.1 & 0.1 \\
$\mathrm{Cu}$ & $\mathbf{3 0 . 7}$ & $\mathbf{1 4 . 2}$ & 5.1 & 3.9 \\
$\mathrm{~Pb}$ & $\mathbf{9 . 3}$ & $\mathbf{7 . 3}$ & 2.3 & 1.5 \\
$\mathrm{~V}$ & $\mathbf{3 . 4}$ & $\mathbf{1 . 1}$ & 0.8 & 11 \\
\hline
\end{tabular}

Trace elements values for aqueous and organic extraction were combined and expressed as total \% composition. Shaded in gray are crustal elements and Non-shaded are anthropogenic elements.

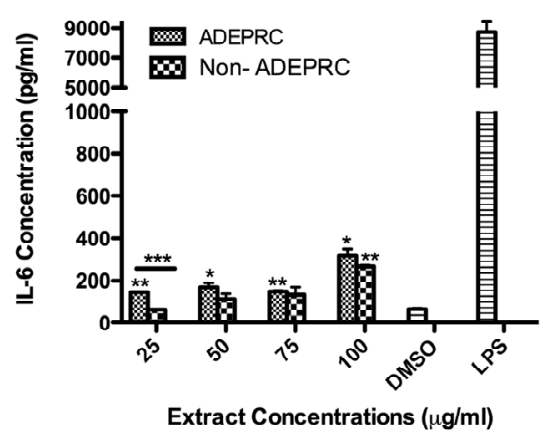

(a)

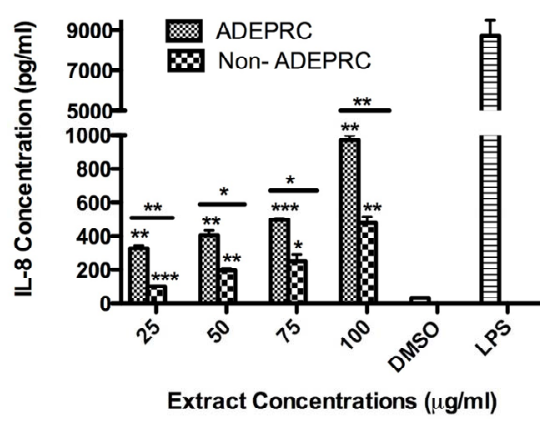

(b)

Figure 8. Induction of IL-6 (a) and IL-8 (b) in BEAS-2B exposed to Puerto Rican coast (ADEPRC) $\mathrm{PM}_{2.5}$ extracts for $24 \mathrm{~h}$. LPS $(10 \mu \mathrm{g} / \mathrm{ml})$ was used as a positive control. Bars represent mean IL-6 and IL-8 concentrations \pm SEM. Stars over the bars indicate comparison of a treatment with DMSO. Stars over the line indicate a comparison between two treatments. All samples were tested in three independent experiments; ${ }^{* * *} \mathrm{p}<0.001,{ }^{* *} \mathrm{p}$ $<0.01, \stackrel{*}{\mathrm{p}}<0.05$.

relative abundance of $\mathrm{Fe}$ and $\mathrm{Al}$ and the contribution to local sources of these two heavy metals.

\section{DISCUSSION}

African dust transports persistent organic pollutants, traces of metals and viable microorganisms across the Atlantic Ocean to the Caribbean, affecting the air quality and impacting human health in the region. However, due to seasonal variations, global climate changes, human activity, PM complexity, and individual characteristics, the health impact and the local environmental factors responsible for triggering PM-adverse effects are difficult to predict and identify. Here, we provide data suggesting that ENX and TMET constituents in PMADEAO/-ADEPRC are responsible for triggering the secretion of pro-inflammatory cytokines and inducing cytotoxicity in human bronchial epithelial cells.

The presence of gram-negative bacteria, containing lipopolysaccharides (LPS) in their cell walls, has been previously reported in African dust clouds crossing the Atlantic Ocean [3]. LPS is an endotoxin (ENX) capable of causing toxicity and immunogenicity due to its lipid 


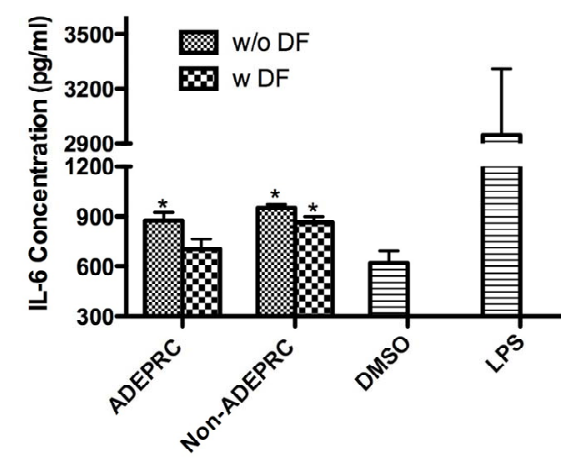

Extract Concentration $(50 \mu \mathrm{g} / \mathrm{ml})$

(a)

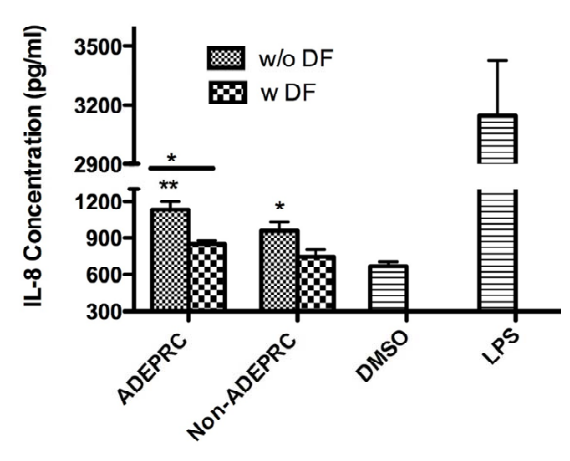

Extract Concentration $(50 \mu \mathrm{g} / \mathrm{ml})$

(b)

Figure 9. Effect of Deferoxamine (DF, a metal chelator) at 50 $\mu \mathrm{M}$ on the induction IL-6 (a) and IL-8 (b) in BEAS-2B exposed to $\mathrm{PM}_{2.5}$ (ADEPRC) extracts for $24 \mathrm{~h}$. Cells were treated with $\mathrm{PM}_{2.5}$ extracts collected during the dust storm (ADEPRC) and non-storm (Non-ADEPRC) season in the presence (w DF) and absence of DF (w/o DF) cytokine induction was measured. LPS $(10 \mu \mathrm{g} / \mathrm{ml})$ was used as a positive control. Bars represent mean IL-6 and IL-8 concentrations \pm SEM. Stars over the bars indicate comparison of a treatment with DMSO. Stars over the line indicate a comparison between two treatments. All samples were tested in three independent experiments; ${ }^{* *} \mathrm{p}<0.01,{ }^{*} \mathrm{p}<$ 0.05 .

and polysaccharide components. LPS elicits a variety of inflammatory responses by activating Toll-like receptor-4 (TLR4) and triggering the signaling cascade mediated by transcription factors such as NF- $\mathrm{KB}$ to secrete pro-inflammatory cytokines (e.g., IL-6, IL-8, TNF- $\alpha$ ); these cytokines at high concentrations may initiate health adverse conditions such as asthma [27,37-38,56-59]. In the present study, ENX was detected in all $\mathrm{PM}_{2.5}$ as well as in $\mathrm{PM}_{10}$ extracts from the Atlantic Ocean and the Puerto Rican coast. The secretion of IL- 6 and IL- 8 was found to increase considerably following PM treatment to BEAS$2 \mathrm{~B}$ cells. TNF- $\alpha$, IL- $1 \beta$, GM-CSF, and MCP-1 were not induced by the PM extracts. More detailed investigations are needed to determine the mechanisms associated with this cellular response using BEAS-2B cells. $\mathrm{PM}_{2.5}$ and $\mathrm{PM}_{10}$ extracts were significantly cytotoxic to BEAS-2B cells; however, the degree of cytotoxicity was not found to be directly dependent on the levels of ENX present in the samples (See Table 1 and Figures 3 and 7). The levels of ENX found in the $\mathrm{PM}_{10}$ extracts collected during Pre-ADEAO (155 EU/mg) were comparable to those $\mathrm{PM}_{10}$ samples collected during ADEPRC (114 EU/mg) and Non-ADEPRC (111 EU/mg); but Pre-ADEAO samples were not cytotoxic to BEAS-2B cells. In addition, $\mathrm{PM}_{10}$ Post-ADEAO samples contained low levels of ENX $(75.9 \mathrm{EU} / \mathrm{mg})$ as compared to the rest of the samples collected but were as toxic as $\mathrm{PM}_{10}$ ADEAO samples which contained the highest ENX concentration (511 EU/mg). In this study, we also found that the levels of ENX present in the $\mathrm{PM}_{10}$ samples collected in the Atlantic Ocean and in the Puerto Rican coast were higher and more cytotoxic than those present in the $\mathrm{PM}_{2.5}$ fractions, which presented the lowest ENX concentrations $(<50 \mathrm{EU} / \mathrm{mg})$. These findings are in agreement with previous studies indicating that ENX content in fine PM fractions $\left(<\mathrm{PM}_{2.5}\right)$, reaching the Caribbean and Puerto Rican coast, is usually lower or negligible when compared to the content in the coarse $\left(<\mathrm{PM}_{10}\right)$ fractions [10,37,59]. Interestingly, PMB, a known LPS inhibitor, did not reduce cell damage caused by the $\mathrm{PM}_{10}$ extracts. In summary, these findings suggest that: 1) ENX were initially deposited onto PM fractions (e.g., $\mathrm{PM}_{10}$ ) during the dust storm originated in the African Continent and gradually lost during its course trajectory through the Caribbean and Puerto Rican coast; 2) ENX content in African dust plays a minor role in the cytotoxicity caused by $\mathrm{PM}_{10}$; and 3) IL-6 and IL-8 were the predominant induced cytokines in this in vitro system, as compared to the rest of the cytokines tested (e.g., TNF- $\alpha$, IL- $1 \beta$, GM-CSF, and MCP-1).

In contrast, the administration of DF (metal chelator) to BEAS-2B cells, treated with ADEPRC-PM 2.5 extracts, significantly reduced the secretion of cytokines and cytotoxicity; supporting the hypothesis that TMET play a major role in causing lung epithelial cell injury in vitro [60]. Previous studies have demonstrated that human airway epithelial cells exposed to metals found in air particles release significant amounts of pro-inflammatory mediators and are toxic in vitro $[61,62]$. In the present study, the concentration of some metals such as $\mathrm{Al}, \mathrm{Cd}$, $\mathrm{Cu}, \mathrm{Fe}, \mathrm{Pb}$ and $\mathrm{V}$ were detected in the $\mathrm{PM}_{2.5}$ fractions during the Non-ADE season but most of these metals increased when ADEAO approached the Puerto Rican coast (Table 2); however, these findings are in disagreement with previous studies which suggested that the levels of TMET present in the ADEAO-PM 2.5 fraction are expected to be lower [10].

The presence of TMET in the atmospheric air, as well as other atmospheric contaminants such as ENX, fluctu- 
ates and is dependent on the source, the frequency and magnitude of each particular dust storm. Studies conducted by the Center for Environmental and Toxicological Research (CETR) at the University of Puerto Rico, Medical Sciences Campus (UPR-MSC) have shown that the influx of African dust affects considerably the air quality conditions in the Northeastern areas of Puerto Rico [12,22,62-67]. These studies have demonstrated that $\mathrm{PM}_{10}$ fractions collected from Puerto Rican urban areas (e.g., Guaynabo, Salinas) contained higher concentrations of ENX and TMET, respectively (e.g., $\mathrm{Cd}, \mathrm{Cu}$, $\mathrm{Fe}, \mathrm{Ni}, \mathrm{Hg}, \mathrm{Pb}$ and $\mathrm{V}$ ) than extracts collected from rural coastal regions (e.g., Fajardo) and were significantly toxic to in vitro systems [12,22,62]. Subsequent work also demonstrated that $\mathrm{PM}_{2.5}$ fractions collected from indoor areas contained higher concentrations of these metals than PM samples obtained from outdoor areas, causing significant release of pro-inflammatory cytokines in vitro [64-68]. These results suggest that $\mathrm{PM}_{2.5}$ and $\mathrm{PM}_{10}$ fractions and some of their constituents (e.g., ENX and TMET) present at different Puerto Rican locations (urban and rural areas) may play a key role in the exacerbation of certain respiratory diseases (e.g. asthma) in predisposed individuals exposed to African dust clouds $[8,10,12]$. Epidemiological studies by the U.S. $\mathrm{CDC}$ and others have reported a high prevalence of asthma, particularly in children $[49,69,70]$. Similar results have also been reported by other investigations performed in the Caribbean region $[46,50,51,54,59,71-$ 74].

Respiratory illnesses such as allergies and asthma are a major concern in Puerto Rico, which has one of the highest asthma prevalence rates in the world between other races/ethnicities, including other Hispanics [69,70, 75]. According to CDC, Puerto Ricans are more likely to have respiratory illness, specifically asthma than white non-Hispanics and total Hispanics. Furthermore, epidemiological studies conducted by the island's health department during 2007 and 2010, indicated that an average of 25,000 cases were filed each year and more than 90,000 adults could not work or perform regular activeties due to suffering of respiratory diseases. Despite of decades of research in this area, it is still uncertain why Puerto Ricans suffer so much from asthma; however health officials in the island suspect that environmental and individual characteristics are responsible for triggering respiratory diseases. $\mathrm{PM}_{2.5}$ and $\mathrm{PM}_{10}$ are a major threat to children because of their higher exposure to ambient PM, mostly when involved in outdoor activities as compared to adults and because of their immature state of the lung and immune system function [72,76]. In addition to ENX and TMET, other particle pollutants such as $\mathrm{PAH}, \mathrm{NO}_{2}, \mathrm{SO}_{2}$, and $\mathrm{O}_{3}$ have also been associated with the pathogenesis of asthma and the increase of
ER visits and hospitalizations of children; inflammation and oxidative stress are considered the major factors responsible for such adverse conditions [48,53,77-78]. A recent report has suggested an epigenetic and genetic variant in ADCYAP1R1 associated with asthma in Puerto Rican children [79]. ADCYAP1R1, also known as $\mathrm{PAC}_{1}$, is a gene encoding for adenylate cyclase activating polypeptide 1 (pituitary) receptor type $\mathrm{I}$. $\mathrm{PAC}_{1}$ is a membrane-associated protein that shares significant homology with members of the glucagon/secretin receptor family. This receptor is highly expressed in the central nervous system (CNS), but it has been found in considerable levels in other tissues (e.g., spinal cord, digestive system, liver, adrenal medulla, and smooth muscle). ADCYA P1R1 mediates diverse biological actions of adenylate cyclase. For example, it regulates stress response across species [80] and also has been linked to post-traumatic stress disorder in adult and anxiety in children.

Another area of intense investigation in recent years is the participation of transient receptor potential (TRP) cation channels and calcium transporters in regulating the acute toxicological effects of ambient PM. The mammalian TRP was initially identified as particle sensors, whose primary function was to regulate the cell membrane permeability to a variety of ions. Subsequently, it was demonstrated that, some of the TRP subfamilies were linked to many pathophysiological and specific diseases; and also capable of mediating airway injury, hyper-reactivity and cardiovascular toxicity of inhaled pollutants [81-88]. The mammalian TRP family consists of six main subfamilies referred to as TRPC, TRPV, TRPM, TRPP, TRPML and TRPA groups. TRPV1, TRPV4, TRPA1, and TRPM8 have been proposed to mediate health adverse effect following exposure to urban air pollution [88-90]. It has been hypothesized that these four TRP subfamily members trigger acute adverse respiratory and cardiovascular effects by mediating calcium influx, activating signal transduction pathways and matrix-metalloproteinases (MMP) [91]. The increased MMP secretion by lung epithelial cells exposed to ambient PM has been linked to respiratory diseases [92-94], including pediatric acute lung injury [95]. Recent work has also demonstrated that TRPV4 polymorphism is associated with COPD [96] and cough in individuals without asthma [97]; and that TRPVI and TRV4 loss of function by a genetic variant lower the risk of active childhood asthma [98]. In addition to TRPs and calcium transporters, humic-like substances (HLS) and cell iron equilibrium have also been associated with lung injury following exposure to ambient PM pollutants $[99,100]$. Studies analyzing function and expression of TRP cellular channels in the lung may enable us to better understand the development of diseases caused by ambient PM and develop new therapeutic strategies for respiratory illnesses 
in the near future. We have briefly discussed the possible contributions and effects of PM constituents in human lung epithelial cells. A summary of the transport of dust storms across the Atlantic Ocean and the possible pathways of PM constituents that may lead to cytokine induction, cytotoxicity and respiratory disease are shown in Figure 10.

Therefore, it is of considerable importance to conduct more defined epidemiological and in vivo and in vitro studies to 1) better understand the precise environmental factors that play a critical role in the ADEPRC-induced
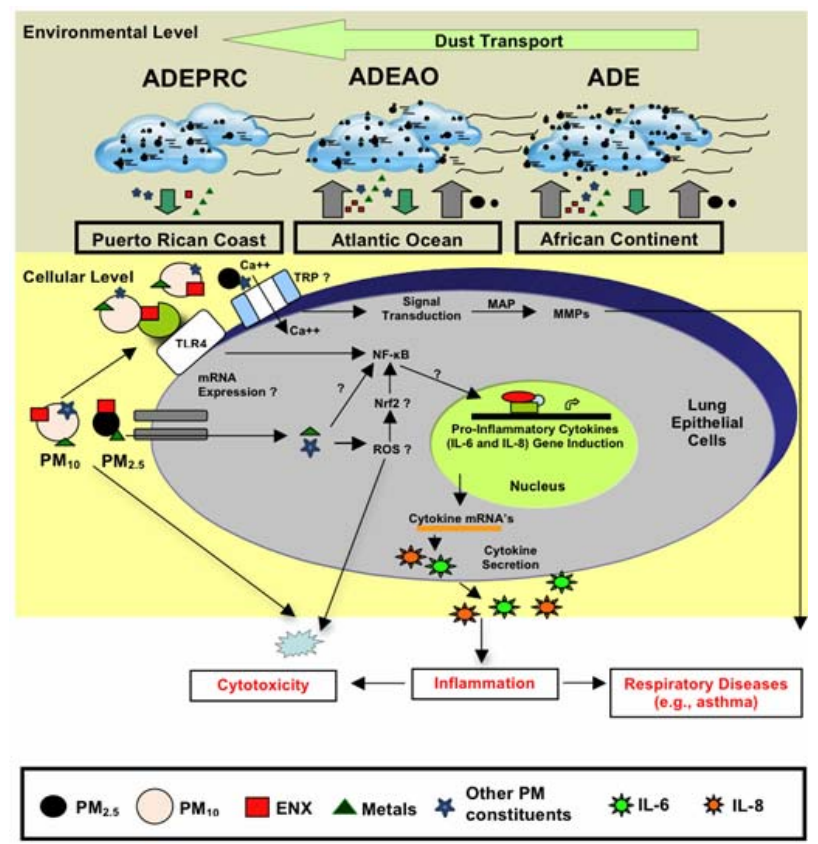

Figure 10. Schematic model explaining the movement of African dust through the Atlantic Ocean (ADEAO) reaching the Puerto Rican coast (ADEPRC) and the possible relationship between its constituents (e.g., $\mathrm{PM}_{2.5-10}$, ENX, TMET, other PM constituents). Briefly, as African dust crosses the Atlantic Ocean, $\mathrm{PM}_{2.5}$ and $\mathrm{PM}_{10}$ distribution along with their constituents are modified. Upon arrival to the Puerto Rican coast, ENX levels are reduced whereas the levels of TMET are increased. ENX and TMET are cytotoxic to human bronchial epithelial cells, and can lead to inflammation and oxidative stress. This detrimental response may be caused due to the release of pro-inflammatory cytokines (e.g., IL-6 and IL-8), activation of nuclear receptor pathways (e.g., NF- $\mathrm{BB}, \mathrm{Nrf} 2$ ), and the formation of reactive oxygen species (ROS). Interrogative symbols (?) represent factors involved in the signal transduction mediating cytokine secretion that are currently under study. Transient receptor potential (TRP) has also been associated with health adverse effects of ambient PM. TRP mediate calcium influx, activate signal transduction pathways (e.g., MAP kinases) and modulate MMP (matrix metalloproteases) causing lung injury. Small circles represent $\mathrm{PM}_{2.5}$ and large circles $\mathrm{PM}_{10}$; Endotoxins (ENX) are represented as red squares, traces of metals (TMET) as green triangles and other potential PM constituents as light blue stars. Cytokines are represented as dark blue and green stars. respiratory related diseases; 2) identify the biological mechanisms that render one population being more susceptible than another to PM health adverse effects; and 3) develop new strategies, educational programs and treatments for the patients and ultimately reduce asthma hospitalization and morbidity rate on the island. Taken together, the present study indicates that ENX and TMET can cause toxic effects to lung cells and TMET is the main responsible for the toxicity seen in this in vitro study. We hypothesize that ENX triggers the release of pro-inflammatory cytokines, such as IL-6 and IL-8, and render the cells more susceptible to PM contaminants such as metals, causing epithelial lung injury. Our findings support previous studies indicating that $\mathrm{PM}_{2.5}$ and $\mathrm{PM}_{10}$ may have the potential to trigger allergic and asthma episodes in susceptible and predisposed individuals, especially in children during ADEPRC season. This research also recognizes the importance of PM size fractions, composition and origin in causing potential lung adverse effects.

\section{ACKNOWLEDGEMENTS}

The authors thank the Puerto Rico Environmental Quality Board for providing $\mathrm{PM}_{10}$ and $\mathrm{PM}_{2.5}$ materials used in this research. Also, we like to thank Dr. Wilfredo Delgado from the University of Puerto Rico, Biochemistry Department, for his help and access to equipment; Dr. Felix Román-Velázquez and graduate student, Diana Sánchez from the University of Puerto Rico Mayagüez Campus, Chemistry Department for the ICP-MS metal analysis and Drs. Roy Amstrong, Yasmin Detrés and Vernon Morris for their involvement in the Atlantic Ocean trip coordination and PM sample collection. The research reported in this publication was supported by the National Institute of General Medical Sciences of the National Institutes of Health under award number R25GM061838. The content is solely the responsibility of the authors and does not necessarily represent the official views of the National Institutes of Health. Infrastructure support was provided in part by grant from the National Institute on Minority Health and Health Disparities (8G12MD007600).

\section{REFERENCES}

[1] Prospero, J.M. and Nees, R.T. (1977) Dust concentration in the atmosphere of the equatorial north Atlantic: Possible relationship to the Sahelian drought. Science, 196, 1196-1198. http://dx.doi.org/10.1126/science.196.4295.1196

[2] Wittig, R., König, K., Schmidt, M. and Szarzynski, J. (2007) A study of climate change and anthropogenic impacts in West Africa. Environmental Science and Pollution Research, 14, 182-189.

http://dx.doi.org/10.1065/espr2007.02.388

[3] Griffin, D.W. (2007) Atmospheric movement of microorganisms in clouds of desert dust and implications for human health. Clinical Microbiology Reviews, 20, 459-477. http://dx.doi.org/10.1128/CMR.00039-06 
[4] Prospero, J.M. and Lamb, P.J. (2003) African droughts and dust transport to the Caribbean: Climate change implications. Science, 302, 1024-1027. http://dx.doi.org/10.1126/science.1089915

[5] Griffin, D.W. and Seba, D.B. (2003) Atmospheric transport of mold spores in clouds of desert dust. Archives of Environmental Health, 58, 498-504.

[6] Chiapello, I., Moulin, C. and Prospero, J.M. (2005) Understanding the long-term variability of African dust transport across the Atlantic as recorded in both Barbados surface concentrations and large-scale Total Ozone Mapping Spectrometer (TOMS) optical thickness. Journal of Geophysical Research, 110, D18S10.

http://dx.doi.org/10.1029/2004JD005132

[7] Monteil, M.A. (2008) Saharan dust clouds and human health in the English-speaking Caribbean: What we know and don't know. Environmental Geochemistry and Health, 30, 339-343.http://dx.doi.org/10.1007/s10653-008-9162-0

[8] Montealegre, F., Chardon, D. and Tarrats, H. (1993) Environmental factors precipitating bronchial asthma exacerbations in southern Puerto Rico: A pilot study. Journal of Asthma, 30, 219-227.

http://dx.doi.org/10.3109/02770909309054520

[9] Reid, J.S., Kinney, J.E., Wastphal, D.L., Holben, B.N., Welton, E.J., Tsay, S.-C., et al. (2003) Analysis of measurements of Saharan dust by airborne and ground-based remote sensing methods during the Puerto Rico Dust Experiment (PRIDE). Journal of Geophysical Research, 108, 8586. http://dx.doi.org/10.1029/2002JD002493

[10] Jiménez-Vélez, B., Detrés, Y., Armstrong, R.A. and Gioda, A. (2009) Characterization of African Dust $\left(\mathrm{PM}_{2.5}\right)$ across the Atlantic Ocean during AEROSE 2004. Atmospheric Environment, 43, 2659-2664.

http://dx.doi.org/10.1016/j.atmosenv.2009.01.045

[11] Trapp, J.M., Millero, F.J. and Prospero, J.M. (2010) Temporal variability of the elemental composition of African dust measured in trade wind aerosols at Barbados and Miami. Atmospheric Environment, 120, 71-82. http://dx.doi.org/10.1016/j.marchem.2008.10.004

[12] Ortiz-Martinez, M., Rivera-Ramirez, E., Mendez-Torres, L. and Jiménez-Vélez, B.D. (2010) Role of chemical and biological constituents of $\mathrm{PM}_{10}$ from Saharan dust in the exacerbation of asthma in Puerto Rico. Biodiversity Science for Humanity, Athens Institute for Educations \& Research, 101-118.

[13] Aust, A.E., Ball, J.C., Hu, A.A., Lighty, J.S., Smith, K.R., Straccia, A.M., et al. (2002) Particle characteristics responsible for effects on human lung epithelial cells. Research Report (Health Effects Institute), 110, 1-65. http://www.ncbi.nlm.nih.gov/pubmed/12578113

[14] Schlesinger, R.B., Kunzli, N., Hidy, G.M., Gotschi, T. and Jerrett, M. (2006) The health relevance of ambient particulate matter characteristics: Coherence of toxicological and epidemiological inferences. Inhalation Toxicology, 18, 95-125. http://dx.doi.org/10.1080/08958370500306016

[15] Schwarze, P.E., Øvrevik, J., Hetland, R.B., Becher, R., Cassee, F.R., Låg, M., et al. (2007) Importance of size and composition of particles for effects on cells in vitro. Inhalation Toxicology, 19, 17-22. http://dx.doi.org/10.1080/08958370701490445

[16] Duzgoren-Aydin, N.S. (2008) Health effects of atmospheric particulates: A medical geology perspective. Journal of Environmental Science and Health Part C: Environmental Carcinogenesis \& Ecotoxicology Reviews, 26, 1-39. http://dx.doi.org/10.1080/10590500801907340

[17] Demerjian, K.L. and Mohnen, V.A. (2008) Synopsis of the temporal variation of particulate matter composition and size. Journal of the Air \& Waste Management Association, 58, 216-233. http://dx.doi.org/10.3155/1047-3289.58.2.216

[18] Bell, M.L., HEI Health Review Committee (2012) Assessment of the health impacts of particulate matter characteristics. Research Report (Health Effects Institute), 161, 5-38. http://www.ncbi.nlm.nih.gov/pubmed/22393584

[19] Garrison, V.H., Foreman, W.T., Genualdi, S.D., Griffin, W., Kellogg, C.A., Majewski, et al. (2006) Saharan dusta carrier of persistent organic pollutants, metals and microbes to the Caribbean? International Journal of Tropical Biology, 54, 9-21.

[20] Morris, V. (2010) Personal Communication. Howard University, Washington DC.

[21] Costa, D.L. and Dreher, K.L.(1997) Bioavailable transition metals in particulate matter mediate cardiopulmonary injury in healthy and compromised animal models. Environmental Health Perspectives, 105, 1053-1060. http://dx.doi.org/10.1289/ehp.97105s51053

[22] Molinelli, A.R., Santacana, G.E., Madden, M.C. and Jiménez, B.D. (2006) Toxicity and metal content of organic solvent extracts from airborne particulate matter in Puerto Rico. Environmental Research, 102, 314-325. http://dx.doi.org/10.1016/j.envres.2006.04.010

[23] Chen, L.C. and Lippmann, M. (2009) Effects of metals within ambient air particulate matter (PM) on human health. Inhalation Toxicology, 21, 1-31. http://dx.doi.org/10.1080/08958370802105405

[24] Lippmann, M. And Chen, L.C. (2009) Health effects of concentrated ambient air particulate matter (CAPs) and its components. Critical Reviews in Toxicology, 39, 865-913. http://dx.doi.org/10.3109/10408440903300080

[25] Ma, J. Y. and Ma, J. K. (2002) The dual effect of the particulate and organic components of diesel exhaust particles on the alteration of pulmonary immune/inflammatory responses and metabolic enzymes. Journal of Environmental Science and Health Part C: Environmental Carcinogenesis \& Ecotoxicology Reviews, 20, 117-147. http://dx.doi.org/10.1081/GNC-120016202

[26] Becker, S., Mundandhara, S., Devlin, R.B. and Madden, M. (2005) Regulation of cytokine production in human alveolar macrophages and airway epithelial cells in response to ambient air pollution particles: further mechanistic studies. Toxicology and Applied Pharmacology, 207, 269-275. http://dx.doi.org/10.1016/j.taap.2005.01.023

[27] Schwartz, D.A. (2001) Does inhalation of endotoxin cause asthma? American Journal of Respiratory and Critical Care Medicine, 163, 305-313. http://dx.doi.org/10.1164/ajrccm.163.2.ed2000a 
[28] de Kok, T.M., Driece, H.A., Hogervorst, J.G. and Briedé, J.J. (2006) Toxicological assessment of ambient and traffic-related particulate matter: A review of recent studies. Mutation Research, 613, 103-122. http://dx.doi.org/10.1016/j.mrrev.2006.07.001

[29] Valavanidis, A., Fiotakis, K. and Vlachogianni, T. (2008) Airborne particulate matter and human health: Toxicological assessment and importance of size and composition of particles for oxidative damage and carcinogenic mechanisms. Journal of Environmental Science and Health Part C: Environmental Carcinogenesis \& Ecotoxicology Reviews, 26, 339-362.

http://dx.doi.org/10.1080/10590500802494538

[30] D'Amato, G. and Cecchi, L. (2008) Effects of climate change on environmental factors in respiratory allergic diseases. Clinical \& Experimental Allergy, 38, 1264-1274. http://dx.doi.org/10.1111/j.1365-2222.2008.03033.x

[31] Huang, Y.C., Li, Z., Carter, J.D., Soukup, J.M., Schwartz, D.A. and Yang, I.V. (2009) Fine ambient particles induce oxidative stress and metal binding genes in human alveolar macrophages. American Journal of Respiratory Cell and Molecular Biology, 41, 544-552. http://dx.doi.org/10.1165/rcmb.2008-0064OC

[32] Brook, R.D., Rajagopalan, S.C., Pope III, A., Brook, J.R., Bhatnagar, A. and Diez-Roux, A.V., et al. (2010) Particulate matter air pollution and cardiovascular disease: An update to the scientific statement from the American Heart Association. Circulation, 2331-2377. http://dx.doi.org/10.1161/CIR.0b013e3181dbece1

[33] Jie, Y., Ismail, N.H., Jie, X. and Isa, Z.M. (2011) Do indoor environments influence asthma and asthma-related symptoms among adults in homes? A review of the literature. Toxicology, 299, 125-132.

http://dx.doi.org.proxy.library.emory.edu/10.1016/j.jfma.2 011.07 .003

[34] de Longueville, F., Ozer, P., Doumbia, S. and Henry, S. (2012) Desert dust impacts on human health: An alarming worldwide reality and a need for studies in West Africa. International Journal of Biometeorology, 3, 1-19.

[35] Van Berlo, D., Hullmann, M. and Schins, R.P. (2012) Toxicology of ambient particulate matter. Molecular, Clinical and Environmental Toxicology: Experientia Supplementum, 101, 165-217. http://dx.doi.org/10.1007/978-3-7643-8340-4_ 7

[36] Weichenthal, S. (2012) Selected physiological effects of ultrafine particles in acute cardiovascular morbidity. Environmental Research, 115, 26-36. http://dx.doi.org/10.1016/j.envres.2012.03.001

[37] Hetland, R.B., Cassee, F.R., Refsnes, M., Schwarze, P.E., Låg, M., Boere, A.J., et al. (2004) Release of inflammatory cytokines, cell toxicity and apoptosis in epithelial lung cells after exposure to ambient air particles of different size fractions. Toxicology in Vitro, 18, 203-212. http://dx.doi.org/10.1016/S0887-2333(03)00142-5

[38] Hetland, R., Cassee, F., Låg, M., Refsnes, M., Dybing, E. and Schwarze, P.E. (2005) Cytokine release from alveolar macrophages exposed to ambient particulate matter: Heterogeneity in relation to size, city and season. Particle and Fibre Toxicology, 2, 1-15.
[39] Abbas, I., Saint-Georges, F., Billet, S., Verdin, A., Mulliez, P., Shirali, P., et al. (2008) Air pollution particulate matter (PM2.5)-induced gene expression of volatile organic compound and/or polycyclic aromatic hydrocarbon-metabolizing enzymes in an in vitro coculture lung model. Toxicology in Vitro, 23, 37-46. http://dx.doi.org/10.1016/j.tiv.2008.09.020

[40] Maier, K.L., Alessandrini, F., Beck-Speier, I., Hofer, T.P., Diabaté, S., Bitterle, E., et al. (2008) Health effects of ambient particulate matter-biological mechanisms and inflammatory responses to in vitro and in vivo particle exposures. Inhalation Toxicology, 20, 319-337.

[41] Billet, S., Abbas, I., Le Goff, J., Verdin, A., Andre', V., Lafargue, P.-E., et al. (2008) Genotoxic potential of polycyclic aromatic hydrocarbons-coated onto airborne particulate matter (PM2.5) in human lung epithelial A549 cells. Cancer Letters, 270, 144-155.

http://dx.doi.org/10.1016/j.canlet.2008.04.044

[42] Shoenfelt, J., Mitkus, R.J., Zeisler, R., Spatz, R.O., Powell, J., Fenton, M.J., et al. (2009) Involvement of TLR2 and TLR4 in inflammatory immune responses induced by fine and coarse ambient air particulate matter. Journal of Leukocyte Biology, 86, 303-312. http://dx.doi.org/10.1189/jlb.1008587

[43] Danielsen, P.H., Loft, S., Jacobsen, N.R., Jensen, K.A., Autrup, H., Ravanat, J.L., et al. (2010) Oxidative stress, inflammation, and DNA damage in rats after intratracheal instillation or oral exposure to ambient air and wood smoke particulate matter. Toxicological Sciences, 118, 574-585. http://dx.doi.org/10.1093/toxsci/kfq290

[44] Zhu, J. and Mohan, C. (2010) Toll-like receptor signaling pathways-therapeutic opportunities. Mediators of Inflammation, 2010, Article ID: 78123. http://dx.doi.org/10.1155/2010/781235

[45] Aust, A.E., Cook, P.M. and Dodson, R.F. (2011) Morphological and chemical mechanisms of elongated mineral particle toxicities. Journal of Toxicology and Environmental Health, Part B: Critical Reviews, 14, 40-75. http://dx.doi.org/10.1080/10937404.2011.556046

[46] Dergham, M., Lepers, C., Verdin, A., Billet, S., Cazier, F., Courcot, D., et al. (2012) Prooxidant and proinflammatory potency of air pollution particulate matter $\left(\mathrm{PM}_{2.5-0.3}\right)$ produced in rural, urban, or industrial surroundings in human bronchial epithelial cells (BEAS-2B). Chemical Research in Toxicology, 25, 904-919. http://dx.doi.org/10.1021/tx200529v

[47] Li, Z., Tighe, R.M., Feng, F., Ledford, J.G. \& Hollingsworth, J.W. (2013) Genes of innate immunity and the biological response to inhaled ozone. Journal of Biochemical and Molecular Toxicology, 27, 3-16. http://dx.doi.org/10.1002/jbt.21453

[48] Rossi, O.V., Kinnula, V.L., Tienari, J. and Huhti, E. (1993) Association of severe asthma attacks with weather, pollen, and air pollutants. Thorax, 48, 244-248. http://dx.doi.org/10.1136/thx.48.3.244

[49] Ledogar, R.J., Penchaszadeh, A., Garden, C.C. and Iglesias, G. (2000) Asthma and Latino cultures: Different prevalence reported among groups sharing same environment. American Journal of Public Health, 90, 929- 
935. http://dx.doi.org/10.2105/AJPH.90.6.929

[50] Gyan, K., Henry, W., Lacaille, S., Laloo, A., LamseeEbanks, C., McKay, S., et al. (2004) African dust clouds are associated with increased paediatric asthma accident and emergency admissions on the Caribbean island of Trinidad. International Journal of Biometeorology, 49, 371-376. http://dx.doi.org/10.1007/s00484-005-0257-3

[51] Prospero, J.M., Blades, E., Naidu, R., Mathison, G., Thani H. and Lavoie, M.C. (2008) Relationship between African dust carried in the Atlantic trade winds and surges in pediatric asthma attendances in the Caribbean. International Journal of Biometeorology, 52, 823-832. http://dx.doi.org/10.1007/s00484-008-0176-1

[52] Karakatsani, A., Analitis, A., Perifanou, D., Ayres, J.G., Harrison, R.M., Kotronarou, A., et al. (2012) Particulate matter and air pollution and respiratory symptoms in individuals having either asthma or chronic obstructive pulmonary disease: A European multicentre panel study. Environmental Health, 11, 75. http://dx.doi.org/10.1186/1476-069X-11-75

[53] Wang, G., Jiang, R., Zhao, Z. and Song, W. (2013) Effects of ozone and the particulate matter $\left(\mathrm{PM}_{2.5}\right)$ on rat system inflammation and cardiac function. Toxicology Letters, 217, 23-33. http://dx.doi.org/10.1016/j.toxlet.2012.11.009

[54] Zora, J.E., Sarnat, S.E., Raysoni, A.U., Johnson, B.A., Li, W.W., Greenwald, R., et al. (2013) Associations between urban air pollution and pediatric asthma control in El Paso, Texas. Science of the Total Environment, 448, 56-65. http://dx.doi.org/10.1016/j.scitotenv.2012.11.067

[55] Li, N., Hao, M., Phalen, R., Hinds, W. and Nel, A. (2003) Particulate air pollutants and asthma A paradigm for the role of oxidative stressing PM-induced adverse health affects. Clinical Immunology, 109, 250-265. http://dx.doi.org/10.1016/j.clim.2003.08.006

[56] Soukup, J.M. and Becker, S. (2001) Human alveolar macrophage responses to air pollution particulates are associated with insoluble components of coarse material, including particulate endotoxin. Toxicology and Applied Pharmacology, 171, 20-26. http://dx.doi.org/10.1006/taap.2000.9096

[57] Veranth. J.M., Reilly, C.A., Veranth, M.M., Moss, T.A., Langelier, C.R., Lanza, D.L., et al. (2004) Inflammatory cytokines and cell death in BEAS-2B lung cells treated with soil dust, lipopolysaccharide, and surface-modified particles. Toxicological Sciences, 82, 88-96. http://dx.doi.org/10.1093/toxsci/kfh248

[58] Valko, M., Morris, H. and Cronin, M.T.D. (2005) Metals, toxicity and oxidative stress. Current Medicinal Chemistry, 11, 1161-1208. http://dx.doi.org/10.2174/0929867053764635

[59] Gualtieri, M., Øvrevik. J., Holme, J.A., Grazia-Perrone, M., Bolzacchini. E., Schwarze, P.E., et al. (2010) Differences in cytotoxicity versus pro-inflammatory potency of different PM fractions in human epithelial lung cells. Toxicology in Vitro, 24, 29-39. http://dx.doi.org/10.1016/j.tiv.2009.09.013

[60] Riley, M.R., Boesewetter, D.E., Kim, A.M. and Sirvent, F.P. (2003) Effects of metals $\mathrm{Cu}, \mathrm{Fe}, \mathrm{Ni}, \mathrm{V}$, and $\mathrm{Zn}$ on rat lung epithelial cells. Toxicology, 190, 171-184.
http://dx.doi.org/10.1016/S0300-483X(03)00162-8

[61] Carter, J.D., Ghio, A., Samet, J. and Devlin, R.B. (1997) Cytokine production by human airway epithelial cells after exposure to an air pollution particle is metal dependent. Toxicology and Applied Pharmacology, 146, 180-188. http://dx.doi.org/10.1006/taap.1997.8254

[62] Reyes, D., Rosario, O., Rodríguez, J.F. and Jiménez, B.D. (2010) Toxic evaluation of organic extracts from airborne particulate matter in Puerto Rico. Environmental Health Perspectives, 108, 635-640.

[63] Acevedo-Figueroa, D., Rodríguez-Sierra, C.J. and Jiménez-Vélez, B.D. (2006) Concentrations of $\mathrm{Ni}$ and V, other heavy metals, arsenic, elemental and organic carbon in atmospheric fine particles $\left(\mathrm{PM}_{2.5}\right)$ from Puerto Rico. Toxicology \& Industrial Health, 22, 87-99. http://dx.doi.org/10.1191/0748233706th247oa

[64] Gioda, A., Pérez, U., Rosa, Z. and Jiménez-Vélez, B.D. (2006) Concentrations of trace elements in airborne $\mathrm{PM}_{10}$ from Jobos Bay National Estuary, Puerto Rico. Water, Air, and Soil Pollution, 174, 141-159. http://dx.doi.org/10.1007/s11270-005-9069-7

[65] Gioda, A., Pérez, U., Rosa, Z. and Jiménez-Vélez, B.D. (2007) Particulate matter $\left(\mathrm{PM}_{10}\right.$ and $\left.\mathrm{PM}_{2.5}\right)$ from different areas of Puerto Rico. Fresenius Environmental Bulletin, 16, 861-868.

[66] Gioda, A., Fuentes-Mattei, E. and Jiménez-Vélez, B. (2011) Evaluation of cytokine expression in BEAS cells exposed to fine particulate matter (PM2.5) from specialized indoor environments. International Journal of Environmental Health Research, 21, 106-119.

http://dx.doi.org/10.1080/09603123.2010.515668

[67] Jiménez-Vélez, B.D., Gioda, A. and Fuentes-Mattei, E. (2006) Organic and aqueous extracts from particulate matter $\left(\mathrm{PM}_{2.5}\right)$ and their effects on the immunological response of BEAS cells. In: Collery, P., Ed., Metal Ions in Biology and Medicine, John Libbey Eurotext, Paris, 267272.

[68] Fuentes-Mattei, E., Rivera, E., Gioda, A., Sanchez-Rivera, D., Roman-Velazquez, F.R. and Jiménez-Vélez. B.D. (2010) Use of human bronchial epithelial cells (BEAS-2B) to study immunological markers resulting from exposure to $\mathrm{PM}_{2.5}$ organic extract from Puerto Rico. Toxicology and Applied Pharmacology, 243, 381-389. http://dx.doi.org/10.1016/j.taap.2009.12.009

[69] Centers for Disease Control and Prevention, National Center for Health Statistics. (2011) Asthma prevalence, health care use, and mortality: United States, 2005-2009. National Health Statistics Reports. http://www.cdc.gov/nchs/data/nhsr/nhsr032.pdf

[70] Centers for Disease Control and Prevention, National Center for Health Statistics. (2012) National surveillance of Asthma: United States, 2001-2010. Vital and Health Statistics. Series 3. http://www.cdc.gov/nchs/data/series/sr 03/sr03 035.pdf

[71] Kanatani, K.T., Ito, I., Al-Delaimy, W.K., Adachi, Y., Mathews, W.C. and Ramsdell, J.W. (2010) Desert dust exposure is associated with increased risk of asthma hospitalization in children. American Journal of Respiratory and Critical Care Medicine, 182, 1475-1481. 
http://dx.doi.org/10.1164/rccm.201002-0296OC

[72] Li, S., Williams, G., Jalaludin, B. and Baker, P. (2012) Panel studies of air pollution on children's lung function and respiratory symptoms: A literature review. Journal of Asthma, 49, 895-910. http://dx.doi.org/10.3109/02770903.2012.724129

[73] Tam, W.W., Wong, T.W., Wong, A.H. and Hui, D.S. (2012) Effect of dust storm events on daily emergency admission for respiratory diseases. Respirology, 17, 143-148. http://dx.doi.org/10.1111/j.1440-1843.2011.02056.x

[74] Manzano-Leon, N., Quintana, R., Sanchez, B., Serrano, J., Vega, E., Vazquez-Lopez, et al. (2013) Variation in the composition and in vitro pro-inflammatory effect of urban particulate matter from different sites. Journal of Biochemical and Molecular Toxicology, 27, 87-97. http://dx.doi.org/10.1002/jbt.21471

[75] Asthma in Puerto Rico: BRFSS analysis for the year 2000. (2002) Asthma Statistical Report. http://www.rcm.upr.edu/publichealth/diabetes/Asthma_St atistical_Report_Vol1.pdf

[76] Heinrich, J. and Slama, R. (2007) Fine particles, a major threat to children. International Journal of Hygiene and Environmental Health, 210, 617-622. http://dx.doi.org/10.1016/j.ijheh.2007.07.012

[77] Samoli, E., Nastos, P.T., Paliatsos, A.G., Katsouyanni, K. and Priftis, K.N. (2011) Acute effects of air pollution on pediatric asthma exacerbation: Evidence of association and effect modification. Environmental Research, 11, 418-424. http://dx.doi.org/10.1016/j.envres.2011.01.014

[78] Saravia, J., Lee, G.I., Lomnicki, S., Dellinger B. and Cormier, S.A. (2013) Particulate matter containing environmentally persistent free radicals and adverse infant respiratory health effects: A review. Journal of Biochemical and Molecular Toxicology, 27, 56-68. http://dx.doi.org/10.1002/jbt.21465

[79] Chen, W., Boutaoui, N., Brehm, J.M., Han, Y.-Y., Schmitz, C., Cressley, A., et al. (2013) ADCYAP1R1 and asthma in Puerto Rican children. American Journal of Respiratory and Critical Care Medicine, 187, 584-588. http://dx.doi.org/10.1164/rccm.201210-1789OC

[80] Jovanovic, T., Norrholm, S.D., Davis, J., Mercer, K.B., Almli, L., Nelson, A., et al. (2012) PAC1 receptor (ADCYAP1R1) genotype is associated with dark-enhanced startle in children. Molecular Psychiatry, 18, 742-743.

[81] Ramsey, S., Delling, M. and Clapham, D.E. (2006) An introduction to TRP channels. Annual Review of Physio$\log y, \mathbf{6 8}, 619-647$.

http://dx.doi.org/10.1146/annurev.physiol.68.040204.100 $\underline{431}$

[82] Nilius, B. (2007) TRP channels in disease. Biochimica et Biophysica Acta, 1772, 805-812. http://dx.doi.org/10.1016/j.bbadis.2007.02.002

[83] Nilius, B., Owsianik, G., Voets, T. and Peters, J.A. (2007) Transient receptor cation channels in disease. Physiological Review, 87, 165-217. http://dx.doi.org/10.1152/physrev.00021.2006

[84] Ghelfi, E., Rhoden, C.R., Wellenius, G.A., Lawurence, J. and Gonzalez-Flecha, B. (2008) Cardiac oxidative stress and electrophysiological changes in rats exposed to concentrated ambient particles are mediated by TRP-dependent pulmonary reflexes. Toxicological Sciences, 102, 328-336. http://dx.doi.org/10.1093/toxsci/kfn005

[85] Deering-Rice, C.E., Romero, E.G., Shapiro, D., Hughen, R.W., Light, A.R., Yost, G.S., et al. (2011) Electrophilic components of diesel exhaust particles (DEP) activate transient receptor potential ankyrin-1 (TRPA1): A probable mechanism of cute pulmonary toxicity for DEP. Chemical Research in Toxicology, 24, 950-959. http://dx.doi.org/10.1021/tx200123z

[86] Deering-Rice, C.E., Johansen, M.E., Roberts, J.K., Thomas, K.C., Romero, E.G., Lee, J., et al. (2012) Transient receptor potential vanilloid-1 (TRPV1) is a mediator of lung toxicity for coal fly ash particulate material. Molecular Pharmacology, 81, 411-419. http://dx.doi.org/10.1124/mol.111.076067

[87] Vennekens, R. (2011) Emerging concepts for the role of TRP channels in the cardiovascular system. The Journal of Physiology, 589, 1527-1534.

http://dx.doi.org/10.1113/jphysiol.2010.202077

[88] Fariss, M.W., Gilmour, M.I., Reilly, C.A., Liedtke, W. and Ghio, A. (2013) Emerging mechanistic targets in lung injury induced by combustion-generated particles. Toxicological Sciences, 132, 253-267. http://dx.doi.org/10.1093/toxsci/kft001

[89] Agopyan, N., Bhatti, T., Yu, S. and Simon, S.A. (2003) Vanilloid receptor activation by 2 - and $10-\mu \mathrm{m}$ particles induces responses leading to apoptosis in human airway epithelial cells. Toxicology and Applied Pharmacology, 192, 21-35. http://dx.doi.org/10.1016/S0041-008X(03)00259-X

[90] Agopyan, N., Li, L., Yu, S. and Simon, S.A. (2003) Negatively charged 2 - and $10-\mu \mathrm{M}$ particles activate vanilloid receptors, increase cAMP, and induce cytokine release. Toxicology and Applied Pharmacology, 186, 63-76. http://dx.doi.org/10.1016/S0041-008X(02)00013-3

[91] Inoue, R., Jensen, J.L., Shi, J., Morita, H., Nishida, M., Honda, A., et al. (2006) Transient receptor potential channels in cardiovascular function and disease. Circulation Research, 99, 119-131. http://dx.doi.org/10.1161/01.RES.0000233356.10630.8a

[92] Segura-Valdez, L., Pardo, A., Caxiola, M., Uhal, B.D., Becerril, C. and Selma, M. (2000) Upregulation of gelatinases $\mathrm{A}$ and $\mathrm{B}$, collagenases 1 and 2, and increased parenchymal cell death in COPD. Chest, 117, 684-694. http://dx.doi.org/10.1378/chest.117.3.684

[93] Joos, L., He, J.Q., Shepherdson, M.B., Connett, J.E., Anthonisen, N.R., Pare, P.D., et al. (2002) The role of matrix metalloproteinase polymorphysms in the rate of decline in lung function. Human Molecular Genetics, 11, 569576. http://dx.doi.org/10.1093/hmg/11.5.569

[94] Atkinson, J. and Senior, R.M. (2003) Matrix metalloproteinase-9 in lung remodeling. American Journal of Respiratory Cell and Molecular Biology, 8, 12-24. http://dx.doi.org/10.1165/rcmb.2002-0166TR

[95] Kong, M.Y.F., Gaggar, A., Li, Y., Winkler, M., Blalock, J.E. and Clancy, J. (2009) Matrix metalloproteinase activity in pediatric acute lung injury. International Journal 
of Medical Sciences, 61, 9-17.

http://www.ncbi.nlm.nih.gov/pmc/articles/PMC2610341/ $\#$ !po=73.0769

[96] Zhu, G., Gulsvik, A., Bakke, P., Ghatta, S., Anderson, W., Lomas, D.A., et al (ICGN Investigators). (2009) Associaiton of TRPV4 gene polymorphism with chronic obstructive pulmonary disease. Human Molecular Genetics, 18, 2053-2062. http://dx.doi.org/10.1093/hmg/ddp111

[97] Smit, L.A.M., Kogevinas, M., Anto, J.M., Bouzigon, E., Gonzalez, J.R., Moual, N.L., et al. (2012) Transient receptor potential genes, smoking, occupational exposures and cough in adults. Respiratory Research, 13, 26. http://dx.doi.org/10.1186/1465-9921-13-26

[98] Cantero-Recasens, G., Gonzalez, J.R., Fandos, C., DuranTauleria, E., Smit, L.A.M., Kauffmann, F., et al. (2010) Loss of function of transient receptor potential vanilloid 1
(TRPV1) genetic variant is associated with lower risk of active childhood asthma. The Journal of Biological Chemistry, 285, 27532-27535. http://dx.doi.org/10.1074/jbc.C110.159491

[99] Ghio, A.J., Stonehuerner, J., Pritchard, R.J., Piantadosi, C.A., Quigley, D.R., Dreher, K.L., et al. (1996) Humiclike substances in air pollution particles correlate with concentration of transition metals and oxidant generation. Inhalation Toxicology, 8, 479-494. http://dx.doi.org/10.3109/08958379609005441

[100] Ghio, A.J., Carraway, M.S. and Madden, M.C. (2012) Composition of air pollution particles and oxidative stress in cells, tissues, and living systems. Journal of Toxicology and Environmental Health, Part B: Critical Reviews, 15, 1-21. http://dx.doi.org/10.1080/10937404.2012.632359 